\title{
MOTIVASI MAHASISWA MEMILIH JURUSAN PENDIDIKAN LUAR BIASA (PLB)
}

\author{
Bhennita Sukmawati \\ IKIP PGRI JEMBER \\ bhennita.sw@gmail.com
}

\begin{abstract}
ABSTRAK
Tujuan penelitian ini, untuk mengetahui motivasi yang dimiliki mahasiswa memilih jurusan PLB, sehingga diperoleh faktor-faktor yang melatarbelakangi motivasi tersebut, diantaranya faktor intrinsik yang berkaitan dengan keinginan atau hasrat dan cita-cita dalam diri dan faktor ekstrinsik yang merupakan faktor dukungan orang tua dan teman. Adapun metode penelitian ini menggunakan metode kualitatif deskriptif yang bertujuan untuk mengungkap data dilapangan yang bersifat aktual mengenai kondisi objektif saat ini. Hasil penelitian, dapat diketahui motivasi mahasiswa memilih jurusan PLB, sebanyak $28 \%$ karena faktor intrinsik yang berkaitan dengan keinginan atau hasrat untuk menjadi seorang guru PLB dan sebesar $27 \%$ memilih karena adanya dorongan cita-cita sehingga mahasiswa banyak yang bersungguh-sungguh dalam belajar dan memahami pelajaran ABK. Selain itu, dalam faktor ekstrinsik sebanyak 24\% memilih jurusan PLB karena adanya dukungan orang tua dan menerima saran orang tua dan sebesar $21 \%$ mahasiswa memilih jurusan PLB karena adanya dorongan teman yang mana temannya banyak memilih jurusan PLB. Simpulan, faktor intrinsik lebih banyak menjadi pertimbangan memilih jurusan PLB dari pada faktor ekstrinsik.
\end{abstract}

Kata Kunci :Motivasi, Pendidikan Luar Biasa (PLB), Mahasiswa

\section{ABSTRACT}

The purpose of this study, to determine the motivation of students choosing the PLB majors, so that the factors behind the motivation obtained, including intrinsic factors related to desires or desires and ideals in themselves and extrinsic factors which are factors of support for parents and friends. The research method uses qualitative descriptive methods that aim to reveal actual field data regarding the current objective conditions. The results of the study showed that the motivation of students to choose the PLB department was $28 \%$ because of intrinsic factors related to the desire or desire to become a PLB teacher and $27 \%$ chose because of the aspirations so that many students were very enthusiastic in learning and understanding $A B K$ lessons. In addition, in extrinsic factors as many as $24 \%$ chose the PLB department because of the support of parents and accepting parental advice and $21 \%$ of students chose the PLB department because of the encouragement of friends whose friends chose the $P L B$ major. Conclusion, more intrinsic factors are taken into consideration in choosing PLB majors than extrinsic factors.

Keywords: Motivation, Extraordinary Education (PLB), Students 


\section{PENDAHULUAN}

Anak Berkebutuhan Khusus (ABK) membutuhkan afeksi khusus dalam hal pendidikan, baik formal maupun informal. Salah satu bentuk perhatian tersebut diantaranya, dengan memberikan peluang yang sama kepada ABK untuk menempuh pendidikan tinggi bersama dengan anak normal lainnya. Pemerintah dalam hal ini memberikan perhatian dengan membuat regulasi tentang Sistem Pendidikan Nasional nomor 20 tahun 2003 pasal 32 ayat 1 dan 2 yang menjelaskan bahwa pendidikan luar biasa adalah pendidikan untuk peserta didik yang memiliki tingkat kesulitan ketika turut mengikuti proses pengajaran diakibatkan ketidak sempurnan mental, emosional, fisik, sosial dan memiliki kemampuan intelektual atau talenta yang istimewa (Setiawan, 2019). Regulasi tersebut diperjelas dengan terbitnya Peraturan Menteri Pendidikan Nasional (Permendiknas) RI nomor 70 tahun 2009 tentang Layanan Pendidikan Inklusif.

Perhatian Pemerintah ini berimplikasi baik bagi eksistensi Anak Berkebutuhan Khusus (ABK), diantaranya menambah peluang ABK untuk meraih cita-cita dan semakin baik penerimaan ABK di masyarakat. Selain itu, ABK mampu mengembangkan skill yang dimiliki melalui pembelajaran yang sedang/sudah ditempuh di lingkup pendidikan formal.

Pendidikan formal Anak Berkebutuhan Khusus (ABK) pada umumnya di Sekolah Inklusi atau Sekolah Luar Biasa (SLB). Dimana dalam sekolah ini ABK mendapatkan pendidikan berdasarkan kurikulum dari Dinas Pendidikan yang sudah dimodifikasi sesuai dengan kebutuhan Anak Berkebutuhan Khusus (ABK). Sehingga ABK memiliki kemampuan dalam menyelesaikan pendidikannya sesuai dengan jenjangnya dan kemampuan yang baik dalam menerima pelajaran.

Faktor yang menjadi kunci kesuksesan dalam pendidikan Anak Berkebutuhan Khusus (ABK) selain dari metode pengajaranya, juga dipengaruhi oleh kompetensi tenaga pendidik atau guru yang mengajar. Tenaga pendidik atau guru ini, banyak memberikan peran yang luar biasa dalam perkembangan dan kesuksesan seorang ABK. Dimana setiap pendidik harus mampu menangani kekurangan yang dimiliki tiap siswa dan mampu memberikan pelajaran sesuai kurikulum yang ada.

Menjadi Guru di sekolah inklusi/sekolah luar biasa ini, memiliki tantangan tersendiri dan tentunya menguji kesabaran, hal ini dikarenakan setiap Anak Berkebutuhan Khusus (ABK) mempunyai beberapa permasalahan dari sisi psikologi, sosial, fisik serta kognitif. Seorang Guru juga dituntut untuk mampu beradaptasi dan mampu memahami setiap karakteristik anak sehingga dapat mengatasi permasalahan yang dialami. Selain itu guru didorong untuk mempunyai kemampuan membantu dan mengajarkan sesuai kebutuhan anak berkebutuhanan khusus serta memiliki kemampuan untuk menyampaikan pelajaran.

Tidak berhenti hanya sekedar tantangan saja, sebutan pahlawan tanpa jasa dalam diri seorang guru melekat dalam kehidupannya, dimana kinerjanya sering kali tidak seimbang dengan dengan penghargaan yang diberikan kepadanya. Hal 
ini diperkuat oleh pernyataan Iskarim, 2013 bahwa penghargaan yang diterima oleh guru tidak sepadan dengan pengabdian yang telah diberikan. Gaji yang diterima oleh guru kurang mencapai kesejahteraan hidup yang layak dari pada profesi lainnya.

Tantangan seorang Guru Anak Berkebutuhan Khusus (ABK) ternyata tidak menyurutkan calon mahasiswa untuk memilih jurusan Pendidikan Luar Biasa ini. IKIP PGRI Jember sebagai salah satu entitas pendidikan tinggi di kota Jember menjawab antusiasme masyarakat terkait Pendidikan Luar Biasa ini, dengan membuka Fakultas Ilmu Pendidikan Program Studi Pendidikan Luar Biasa. Bertambahnya mahasiswa PLB ini, memunculkan suatu pertanyaan yang besar, meskipun tantangan yang akan dihadapi tidak mudah namun animo untuk memilih jurusan PLB tersebut semakin meningkat setiap tahunnya. Mahasiswa akan merasakan bagaimana memahami anak berkebutuhan khusus, memberi pengajaran, mampu menggunakan bahasa isyarat serta diminta untuk sering berinteraksi dengan mahasiwa luar biasa ini. Namun ternyata hal tersebut tidak menyurutkan keinginan untuk memilih jurusan PLB.

Keinginan memilih jurusan PLB tergantung kepada motivasi dalam dirinya. Motivasi sendiri merupakan stimulan yang muncul dalam diri seseorang untuk meraih keinginan. Michel J. Jucius menyampaikan motivasi merupakan aktivitas memberikan dukungan terhadap individu atau diri sendiri untuk menindak lanjuti suatu hal yang menjadi harapan. Sedangkan motivasi setiap orang berbeda- beda tergantung terhadap tujuan mahasiswa. Seperti halnya disampaikan Mc. Donald (Sardiman, 2011) bahwa motivasi, sebagai semangat dalam diri seseorang yang muncul dari insting, didahului dengan adanya tanggapan terhadap harapan yang diinginkan.

Mahasiswa tentunya memiliki motivasi memilih jurusan PLB. Dalam memilih jurusan Herzberg's menyampaikan terdapat motivasi intrinsik dan motivasi ekstrinsik. Motivasi intrinsik merupakan suatu daya gerak dinamis yang tidak memerlukan rangsangan dari luar, sebab dalam internal setiap orang sudah terdorong untuk melakukan aktivitas. Dorongan datang dalam dinya karena sangat berpengaruh pada dirinya untuk hasil yang ingin dicapai. Faktor dari motivasi intrinsik dipengaruhi oleh 1 . Keinginan/hasrat yaitu cara untuk meraih suatu keinginan yang didasari dengan tujuan yang kuat untuk mencapai suatu prestasi yang tinggi dan niat yang kuat seseorang untuk mencapai hasil yang maksimal. 2. Adanya keinginan mencapai cita-cita seseorang memilih suatu jurusan karena ada tujuan tertentu yang melatarbelakanginya. Tujuan untuk mendapatkan keinginan untuk menambah taraf kehidupan individu serta keluarga. Adanya keinginan mendapatkan suatu pekerjaan yang memiliki peluang besar yang bermartabat meskipun sedikit dari pada yang tidak terlalu bergengsi.

Sedangkan motivasi ekstrinsik atau dorongan yang dari luar dirinya untuk menentukan jurusan yang diinginkan. Motivasi berasal dari kedua orang tua atau kerabat dan dorongan dari kolega. Motivasi ekstrinsik dipengaruhi oleh yaitu 1. 
motivasi keluarga merupakan lapisan sosial pertama yang dirasakan individu, yang dapat dikatakan bahwa anak mengenal lapisan sosial pertama kali dalam keluarga. Pertimbangan memilih jurusan yang dipilih karena ada lingkungan terdekat yaitu orang tua atau keluarga dekat. Orang tua selalu memberikan dukungan dan saran untuk meraih cita-cita yang diinginkan. 2. Dorongan yang diberikan teman juga memiliki pengaruh terhadap motivasi mahasiswa dalam memilih jurusan, mahasiswa terkadang masih bingung dengan bakat yang dimiliki sehingga mereka lebih terpengaruh oleh pilihan dan saran teman.

Mahasiswa memiliki Motivasi tersendiri untuk lebih memilih jurusan PLB ini dengan berbagai tantangan yang akan dihadapi, daripada jurusan yang lainnya. Padahal IKIP JEMBER Fakultas Ilmu Pendidikan terdapat 2 (dua) Jurusan yaitu BK (Bimbingan dan Konseling) dan PAUD (Pendidikan Anak Usia Dini). Tujuan penelitian ini adalah untuk mengetahui motivasi yang dimiliki mahasiswa memilih jurusan PLB, sehingga diperoleh faktor-faktor yang melatarbelakangi motivasi memilih jurusan tersebut.

\section{METODE PENELITIAN}

Metode yang digunakan dalam penelitian ini adalah kualitatif deskriptif. Metode deskriptif memiliki tujuan untuk mengungkapkan data yang di lapangan yang bersifat aktual yang berkaitan dengan kondisi objektif (Cresweell, 2012). Penelitan ini dengan menggunakan kualitatif deskriptif yang memiliki tujuan untuk menggali secara objektif motivasi mahasiswa memilih jurusan PLB. Adapun subjek penelitian ini adalah mahasiswa yang sudah kuliah di prodi PLB dengan subjek 30 orang. Data yang telah terkumpul kemudian dianalisis dan dijadikan dasar sebagai hasil dari penelitian tentang motivasi mahasiswa memilih jurusan PLB. Penelitian ini menggunakan teknik wawancara secara terstruktur dan dokumentasi. Proses wawancara tersruktur ini dilakukan kepada mahasiswa PLB dengan menjawab beberapa pertanyaan tersusun secara teratur yang disesuaikan dengan maksud penelitian. Sedangkan dokumentasi digunakan untuk menambah eviden disaat melakukan penelitian.

Analisis data yang digunakan dalam penelitian, menggunakan beberapa langkah sebagai berikut yang pertama reduksi data yang artinya merangkum dan memilih suatu hal yang utama serta mengfokuskan pada hal yang berguna sehingga peneliti mampu menarik kesimpulan. Yang kedua melakukan rangkuman dari temuan berdasarkan aspek yang telah diteliti, disarankan, display atau diorganisasikan dengan baik, tersusun dan terdapat pola hubungan. Yang ketiga dilakukan pemeriksaan data dengan mempelajari kembali informasi yang terkumpul dan menarik kesimpulan. Pengujian kredibilitas data diperlukan untuk mengecekan data yang dilaporkan dengan informasi yang berasal dari objek penelitian (Creswell, 2012). 


\section{HASIL DAN PEMBAHASAN}

Teori motivasi yang dikembangkan Herzberg's yang menyampaikan motivasi adalah faktor intrinsik yang berasal dalam diri pribadi dan faktor Ekstrinsik yang berasal dari luar pribadi seseorang yang bisa menentukan prilaku dalam kehidupan seseorang (Yusoff, Kian \& Idris, 2013). Berdasarkan hasil wawancara pada mahasiswa PLB dengan menggunakan teori motivasi diketahui bahwa secara keseluruhan mahasiwa memiliki motivasi memilih jurusan PLB karena dipengaruhi faktor intrinsik yaitu kenginan atau hasrat sebesar 28\%, artinya motivasi mahasiwa memilih jurusan PLB sebanyak $28 \%$ dikarenakan keinginan/hasrat. Keinginan/hasrat merupakan keinginan yang kuat atau ambisi untuk meraih suatu tujuan.

Hal ini diperkuat oleh McMclelland bahwa setiap individu memiliki keinginan yang kuat untuk berhasil (Hendrydi, 2013). Faktor intrinsik yaitu Hasrat/keinginan dari mahasiswa jurusan PLB dijadikan sebagai modal mencari pekerjaan, dimana jurusan PLB memiliki peluang yang besar menjadi guru. Pekerjaan merupakan suatu kebutuhan sehingga jurusan PLB dijadikan modal mencari pekerjaan dan memiliki peluang menjadi guru yang merupakan bagian dari individu yang berjuang untuk memperoleh tujuan atau pencapaian pribadi. Selain itu pekerjaan menjadi guru motivasi untuk keberhasilan dalam kehidupan yang datang dalam dirinya. Sepertinya disampaikan Frederic Herzberg's salah satu faktor motivasi adalah pekerjaan (Sedermawayanti, 2001). Hal ini akan menjadikan seseorang menjadikan guru professional. Hal ini diperkuat oleh G.R. Terry \& Leslie W.Rue (2009) bahwa motivasi yang paling berhasil adalah suatu yang dapat membuat seseorang menuntaskan aktivitas dengan baik dan penuh semangat karena orang adanya keinginan dalam dirinya untuk melakukannya.

Selanjutnya sebanyak $27 \%$ mahasiswa PLB memilih jurusan PLB dikarenakan motivasi instrinsik yaitu cita-cita. Dimana cita - cita ini merupakan target yang ingin dicapai maka mahasiswa dituntut untuk giat belajar,memiliki keinginan mendalami ilmu PLB serta memiliki kesungguhan untuk memahami lebih dalam yang berkaitan dengan PLB. Usaha yang dilakukan mahasiswa membuktikan memiliki minat yang besar terhadap PLB untuk menggapai cita cita. Sejalan dengan pendapat Dimyati (2002) yang mengatakan munculnya citacita akan bersamaan dengan adanya harapan untuk memunculkan semangat belajar yang baik. Harapan yang dimiliki memberikan dorongan untuk belajar baik dari dalam maupun dari luar dirinya, sehingga akan menghasilkan aktualisasi diri dalam dirinya.

Sedangkan $24 \%$ mahasiswa memilih jurusan PLB karena motivasi ekstrinsik yaitu dorongan keluarga. Pada penelitian ini mahasiswa memilih jurusan PLB karena motivasi peran orang tua. dimana orang tua mereka mendukung dan menyarankan untuk memilih jurusn PLB. Orang tua merupakan seseorang yang mampu memberikan motivasi yang baik hal ini dikarenakan orang tua memiliki pengaruh psikologis terhadap anak. Selain itu, orang tua memiliki 
kedekatan dengan anak yang sangat lama yang mampu memahami kebutuhan dan kemampuan anak sehingga orang tua mampu memberikan dorongan yang kuat untuk anak untuk meraih kehidupan yang lebih baik. Ketika dukungan dari kerabat maupun kolega dirasakan sebagai kenyaman moral dan mental (Baron \& Byrne, 2005). Maka dukungan yang diberikan orang tua akan mampu mempengaruhi untuk memilih jurusan PLB

Selanjutnya sebanyak $21 \%$ memilih jurusan PLB karena motivasi ekstrinsik yaitu dorongan teman. Teman seumuran merupakan sekelompok individu dengan memiliki umur yang sama (Santrock, 2003). Teman seumuran membuat sebuah kelompok yang akhirnya sering mengadakan pertemuan dan memiliki ketertarikan yang sama. Smet (2004) menyampaikan bahwa dukungan teman atau keluarga terdiri dari informasi secara lisan maupun moral, bantuan yang dilakukan secara nyata atau tindakan karena keakraban sosial dan kahadiran yang bermanfaat. Ketika ada perasaan nyaman, rasa peduli, rasa dihargai,dan bantuan teman sehingga merasa adanya dukungan sosial. Ketika dukungan lapisan pertama dalam masyarakat sebagai kenyaman moral dan mental yang diberikan teman - temannya (Baron \& Byrne, 2005). Ketika temannya banyak yang memilih jurusan PLB disertai lingkungan pergaulan yang mendukung untuk itu maka mahaiswa tersebut akan memilih dukungan yang diberikan temannya dengan memilih jurusan PLB

\section{SIMPULAN}

Penelitian ini menghasilkan, bahwa dapat diketahui motivasi mahasiswa memilih jurusan PLB, sebanyak 28\% karena faktor intrinsik yang berkaitan dengan keinginan / hasrat untuk menjadi seorang guru PLB dan sebesar 27\% memilih karena adanya dorongan cita - cita sehingga mahasiswa banyak yang bersunggu-sungguh dalam belajar dan memahami pelajaran ABK. Selain itu, dalam faktor ekstrinsik sebanyak 24\% memilih jurusan PLB karena adanya dukungan orang tua dan menerima saran orang tua dan sebesar $21 \%$ mahasiswa memilih jurusan PLB karena adanya dorongan teman yang mana temannya banyak memilih jurusan PLB. Dari penjabaran diatas dapat diketahui bahwa faktor intrinsik lebih banyak menjadi pertimbangan memilih jurusan PLB dari pada faktor ekstrinsik.

\section{DAFTAR PUSTAKA}

Baron, \& Byrne. (2005). Psikologi Sosial (Jilid 2). Jakarta:Erlangga

Cresweel, J. (2012). Educational Research: Planning, Conducting, and Evaluating Quantitatif and Qualitiative Research. Bostom

Dimyati \& Mudjiono. (2002). Belajar dan Pembelajaran. Jakarta : DEPDIKBUD dan PT. Rineka Cipta.

Hendryadi. (2013). Teori Motivasi Kebutuhan McClelland. 17 Januari 2018. https://teorionline.net/teori-motivasi-kebutuhan-mcclelland/. 
Sardiman. (2011). Interaksi dan Motivasi Belajar Mengajar. Jakarta: Raja Grafindo Persada.

Santrock. J. W. (2003). Adolescence "Perkembangan Remaja". Jakarta : Erlangga.

Sedarmayanti. (2001).Sumber Daya Manusia dan Produktivitas Kerja. Bandung: CV. Mandar Maju

Smet, B. (2004). Psikologi Kesehatan. Jakarta: PT Gramedia Widiasarana.

Terry, George R. \& Leslie W.Rue. (2009).Dasar-dasar Manajemen. Terjemahan.Bekerjasama dengan.G.A.Ticoalu. Jakarta: Bumi Aksara.

Yusoff, W., Kian, T., \& Mohammed Idris, M. (2013)_. Herzberg's Two Factor Theory On Work Motivation: Does It Works for Today's Environment?. Global Journal of Commerce \& Management Perspective. Http://www.gifre.org/admin/papers/gjcmp/herzbergs-2-5-gjcmp Accessed may 11th Pp.18-22. 